\title{
A specialist detritivore links Spartina alterniflora to salt marsh food webs
}

\author{
John D. Parker ${ }^{1,2, *}$, Joseph P. Montoya ${ }^{1}$, Mark E. Hay ${ }^{1}$ \\ ${ }^{1}$ School of Biology, Georgia Institute of Technology, Atlanta, Georgia 30332, USA \\ ${ }^{2}$ Present address: Smithsonian Environmental Research Center, 647 Contees Wharf Road, Edgewater, Maryland 21037, USA
}

\begin{abstract}
Because most plant production is subject to senescence and is eventually consumed by detritivores, the factors that drive detritivore diet choice are pivotal to the flow of energy and materials through food webs. Here, we investigated the common salt marsh amphipod Gammarus palustris, which is a habitat specialist that feeds specifically on the dead leaves of its living host plant, salt marsh cordgrass Spartina alterniflora. Restricted use and consumption of dead S. alterniflora was reinforced by superior amphipod performance (survival, size, and sexual development) on dead $S$. alterniflora relative to other diets, and was driven at least in part by amphipods being physically able to feed on soft, decaying plant tissues but not live, turgid tissues. Stable isotopes from field surveys and laboratory assimilation assays suggest that amphipods also feed on $S$. alterniflora in the field, and that the important marsh fish Fundulus hetroclitus feeds on amphipods. Thus, consumption of G. palustris by $F$. heteroclitus may be an important trophic pathway linking cordgrass production to nearshore food webs. Importantly, direct isotopic analyses of amphipods and their known food sources demonstrated substantial deviation of observed fractionation factors from idealized standards. This suggests caution when using idealized trophic shifts to describe food web linkages, and a renewed focus on assimilation assays to determine the realized fractionation of dietary isotopes.
\end{abstract}

KEY WORDS: Spartina alterniflora $\cdot$ Detritus $\cdot$ Stable isotopes $\cdot$ Food webs

\section{INTRODUCTION}

A rich literature describes the ecological and evolutionary causes and consequences of herbivore diet choice (Rosenthal \& Berenbaum 1992). Rather than being eaten alive, however, most plants senesce and are processed via detrital food webs (Mann 1988, Cebrian 1999). Detrital pathways infuse food webs with plant production even in the relative absence of herbivory, and influence nearly all ecosystems (Polis \& Strong 1996). Thus, the factors that drive feeding on detritus rather than live tissues are pivotal to the flow of energy and materials through food webs.

Salt marshes dominated by smooth cordgrass Spartina alterniflora Loisel are among the world's most productive ecosystems and support ecologically and economically important communities (Silliman \& Bor- tolus 2003). However, herbivores generally consume much less than $10 \%$ of marsh plant production (Teal 1962, Silliman \& Newell 2003), and most cordgrass senesces and decays while still attached to the stem (Newell 1993). The trophic importance of cordgrass detritus has been debated for decades, with plant detritus often considered too nutritionally inadequate to be the sole food source supporting detritivore production (Odum et al. 1979). However, benthic macro-organisms such as shredder snails, amphipods, and shrimps are particularly common on the marsh surface and will eat dead cordgrass, at least in laboratory settings (e.g. Rietsma et al. 1988, Bärlocher \& Newell 1994, Kneib et al. 1997, Pennings et al. 1998). Moreover, stable isotope evidence consistently demonstrates the presence of cordgrass carbon in nearshore food webs (Currin et al. 1995). Thus, cord- 
grass production is likely assimilated and passed up the food chain. However, the pathways and mechanisms linking cordgrass production to nearshore food webs remain unclear, in part because few studies explicitly link consumer diet choice to food web structure (Winemiller et al. 2007).

In this study, we investigated the feeding preferences and trophic position of the salt marsh amphipod Gammarus palustris, which is a common, although visually cryptic, amphipod in salt marshes along the eastern Atlantic coast of the United States, from New Hampshire to Florida (Gable \& Croker 1977). It is found clustered in and around the interstices created by the outer leaves, stems, and root masses of Spartina alterniflora, with densities reported at up to 55000 ind. $\mathrm{m}^{-2}$ (Van Dolah 1978). Previous studies suggest that $G$. palustris is a generalized consumer of macro- and epiphytic algae found on the marsh surface (Gable \& Croker 1977, Guarna \& Borowsky 1993), although direct observations of gut contents found a 'large amount of unidentifiable detritus' (Gable \& Croker 1977, p. 129). Given its abundance, widespread distribution, and close association with cordgrass, we hypothesized that G. palustris could be a major link between marsh primary production and higher trophic levels if it feeds directly on decaying salt marsh cordgrass. We asked the following questions: (1) What are the dietary preferences of G. palustris? (2) What food traits affect diet selection? (3) Does amphipod fitness on different macrophyte diets reinforce patterns of preference? (4) What do stable isotope analyses reveal about the natural diet of $G$. palustris and of marsh food web structure at our study site?

\section{MATERIALS AND METHODS}

Our study site was a salt marsh at the Georgia Institute of Technology's marine lab on Skidaway Island, Georgia, USA. Shorelines in this estuarine environment are dominated by smooth cordgrass Spartina alterniflora interspersed with a fringing band of oyster Crassostrea virginica reef in the middle intertidal, and sparse cordgrass, mud, and sand sediments in the lower intertidal. Tidal range varies from 2 to $4 \mathrm{~m}$. Previous studies found the salt-marsh amphipod Gammarus palustris closely associated with $S$. alterniflora (Gable \& Croker 1977, van Dolah 1978); our findings at this site were similar. During the $2 \mathrm{yr}$ of these experiments, repeated daytime and nighttime inspections never revealed G. palustris in the upper intertidal, on standing dead, heavily epiphytized cordgrass stems, or in the water column. The amphipod was found only within the leaf interstices of live $S$. alterniflora where the older blades were senescing.
Amphipod feeding preferences. Previous studies suggested that Gammarus palustris feeds primarily on small epiphytes (Gable \& Croker 1977) or macroalgae (Guarna \& Borowsky 1993), but not on cordgrass despite its close association with this plant. To determine G. palustris feeding preferences among cordgrass and other macrophytes common to our study site, we conducted no-choice and multiple choice feeding assays in the laboratory with 3 algal species (the green alga Ulva sp. (henceforth Ulva), and 2 epiphytic red algae common on cordgrass stems, Bostrychia radicans [Montagne] Montagne and Caloglossa leprieurii [Montagne] J. Agardh) and 4 types of cordgrass: the tips of newly sprouted shoots, live green tissue from the upper blades of older plants, yellowing, senescent leaves, and dead, decomposing blades located near the base of the stem.

For no-choice assays, we placed 2 amphipods into each of 5 replicate $3.3 \mathrm{~cm}$ diameter cups with $50 \mathrm{ml}$ of filtered estuarine water and approximately $0.17 \mathrm{~g}$ of plant tissue that had been pre-weighed after blotting. Controls for changes in plant mass unrelated to amphipod consumption consisted of identical portions from the same plants placed into cups without amphipods. Water was changed daily and all feces removed. After $92 \mathrm{~h}$, each plant was blotted and re-weighed. We calculated the mass of plant eaten by individual consumers using: $\left(T_{\mathrm{i}} \times C_{\mathrm{f}} / C_{\mathrm{i}}\right)-T_{\mathrm{f}}$, where $T_{\mathrm{i}}$ and $T_{\mathrm{f}}$ were initial and final wet masses of tissue exposed to amphipods, and $C_{\mathrm{i}}$ and $C_{\mathrm{f}}$ were initial and final wet masses of controls. Feeding on each diet was analyzed with a paired $t$-test (treatment versus control); differences in consumption among diets were analyzed with a 1-way analysis of variance (ANOVA) followed by Tukey multiple comparison tests.

For multiple choice assays, 5 amphipods were offered the 7 plant diets together in 13 replicate $8 \mathrm{~cm}$ Petri dishes filled with $100 \mathrm{ml}$ of filtered river water. Controls were identical dishes without amphipods; water was changed daily in all dishes. After approximately $92 \mathrm{~h}$, individual plant portions from each dish were blotted and re-weighed to estimate the mass of plant eaten during the assay (calculated as above). Results were analyzed via Friedman's test followed by multiple comparisons.

Nitrogen is often limiting for detritivores and herbivores (Mattson 1980); thus we also tested whether Gammarus palustris would ingest nitrogen-rich animal matter if given the chance (e.g. via food falls on the marsh surface). We conducted choice and no-choice feeding assays according to the procedures outlined above using lyophilized, powdered, and reconstituted gel-like foods made from the following plant and animals common to salt marshes: dead cordgrass, body tissue from the mud snail Ilyanassa obsoleta, the killi- 
fish (mummichog), Fundulus heteroclitus, and the grass shrimp Palaemonetes vulgaris. Each gel-based diet consisted of $0.5 \mathrm{~g}$ of powdered tissue poured directly into a warm $4 \%$ agar solution, poured onto a fiberglass window screen mesh (mesh size: $0.42 \mathrm{~mm}^{2}$ ), and then pressed between 2 sheets of waxed paper. This method allowed feeding rate to be quantified as the number of window screen squares from which the agar-based 'food' had been grazed over a given period of time (Hay et al. 1998). No-choice assays were run with 1 amphipod per $50 \mathrm{ml}$ container; choice assays were run with 3 amphipods per $350 \mathrm{ml}$ container to better capture significant feeding on the larger amount of plant tissues presented in these assays. After $24 \mathrm{~h}$ and no apparent feeding, we added 1 and 3 amphipods to each no-choice and choice assay container, respectively. Experiments were terminated after $66 \mathrm{~h}$. Results from no-choice and choice assays were analyzed with a Kruskal-Wallis and a Friedman test, respectively, followed by multiple comparisons.

Plant traits affecting feeding preferences. To assess how variations in plant species toughness or texture altered amphipod feeding preferences, we standardized plant structure by freeze-drying each plant, grinding it to a fine powder, incorporating this into a gel-based food poured onto window screen, and offering these to amphipods in a no-choice assay. Assays included Ulva, Caloglossa leprieurii, Bostrychia radicans, and the 4 types of Spartina alterniflora (live, senescent, dead, and shoots). Each replicate consisted of 1 amphipod in a separate container. There were 10 independent replicates for each food type, and feeding was measured after $92 \mathrm{~h}$. If an amphipod died, that replicate was excluded (thus, $\mathrm{N}=8$ to 10 for each treatment). Before freeze-drying, plant toughness was assessed using a penetrometer to determine the mass required to pierce each plant. We also determined the elemental composition ( $\% \mathrm{~N}$ and $\% \mathrm{C}$ ) of plant or animal matter using a Carlo Erba NC 2500 elemental analyzer interfaced to a Micromass Optima mass spectrometer.

Amphipod performance on different diets. To determine how amphipod performance on different diets related to feeding preference, we measured survival, final size, and sexual maturity on sibling groups of newborn amphipods reared on each of the 7 marsh plant diets and on a starvation control. We obtained offspring from 48 ovigerous females collected from Priest Landing marsh on 15 and 17 June 2000. Each mother was placed into an individual Petri dish with filtered river water and 1 pellet of commercial fish food. Water and food were changed every 2 to $3 \mathrm{~d}$. Newborn $(<24 \mathrm{~h}$ old) amphipods were placed into separate Petri dishes and started on 1 of the 8 treatments.
Food preference in Gammarus palustris is under genetic control (Guarna \& Borowsky 1993). Thus, we tested for familial differences in diet-related performance by rearing the entire brood from each mother on the same diet and by contrasting 3 to 6 families per diet (resulting in 30 to 40 ind. per diet). Mothers were preserved at death or after the molting process caused the release of the last juvenile.

Petri dishes were checked daily to assess survivorship. Water and dishes were changed every 3 to $5 \mathrm{~d}$. Food was replaced if there were signs of algal colonization, when plant tissues senesced, or approximately every 7 to $10 \mathrm{~d}$, whichever came first. After $28 \mathrm{~d}$, each survivor was fixed in $5 \%$ formalin. Final sizes of all surviving amphipods and mothers were determined by photographing each amphipod under a microscope and measuring the total length from the tip of the rostrum to the tip of the telson using the segmented line feature in Scion Image software. Surviving female amphipods were considered sexually mature if we observed ripe gonadal tissue through the body wall.

To assess whether amphipod survivorship differed among diets, we performed a parametric survival analysis of the number of days each amphipod persisted on each diet, with data best fitting a lognormal distribution; data were right censused to reflect that some animals did not perish during the $28 \mathrm{~d}$ experiment. To assess which diets led to higher or lower survivorship, we then performed $\chi^{2}$ tests on survivorship at the end of the experiment. The effect of diet on final size was analyzed with 1-way ANOVA followed by Tukey's test. Maternal and brood size effects on offspring final size were assessed via linear regression. The proportion of females that reached sexual maturity among diet treatments was analyzed with a $\chi^{2}$ test. Familial differences in amphipod survival were assessed with 1-way ANOVAs for each diet.

Stable isotope determination of marsh producers and consumers. To determine the diet source of amphipod production in situ and to get a general picture of the food web at our site, we determined the mean values of $\delta^{15} \mathrm{~N}$ and $\delta^{13} \mathrm{C}$ for sediments (mud and sand), macrophyte producers (all diet types listed above), and the following marsh consumers: the amphipods Gammarus palustris and Uhlorchestia spartinophila (a sympatric cordgrass stem-dwelling amphipod that specializes on fungal hyphae; Covi \& Kneib 1995, Kneib et al. 1997), the killifish Fundulus heteroclitus, the snail Ilyanassa obsoleta, and the shrimp Palaemonetes pugio. Mud and sand samples provided a general picture of the detrital and microalgal food sources present on the marsh surface; the remaining samples provided a picture of carbon flow from producers to higher trophic levels. Initial samples were collected from the field in year 2000 , dried at $45^{\circ} \mathrm{C}$, ground via mortar and pestle, and acidified with dilute $\mathrm{HCl}$ to 
remove inorganic carbon. Subsamples (ca. $400 \mu \mathrm{g}$ ) were then weighed and packed into a tin capsule for elemental and isotope analysis by continuous-flow isotope ratio mass spectrometry (CF-IRMS) using a Carlo Erba NC 2500 elemental analyzer interfaced to a Micromass Optima mass spectrometer.

We also ran 2 experiments where amphipods were fed a known diet from birth to examine trophic fractionation factors used in food web studies (DeNiro \& Epstein 1978, 1981, Minagawa \& Wada 1984, Vanderklift \& Ponsard 2003). First, we analyzed the isotope values of the $28 \mathrm{~d}$ old amphipods from the performance experiment described earlier. However, these amphipods had been initially fixed in formalin, and formalin can alter $\delta^{13} \mathrm{C}$ values (Sarakinos et al. 2002). Thus, we repeated the experiment at a smaller scale the following year. For this experiment, we reared 8 or 9 amphipods on each of 4 diets, including dead and senescent Spartina alterniflora, mud, and sand for 29 to $36 \mathrm{~d}$. At the end of the experiment, each amphipod was preserved and processed as before but was never placed in formalin. Surviving amphipods ( $N=4$ to 8 ) and their diet sources were subjected to elemental and isotope analyses as described above.

\section{RESULTS}

\section{Amphipod feeding preferences}

In no-choice feeding assays, amphipods could be demonstrated to have fed on dead Spartina alterniflora, senescent $S$. alterniflora, and the epiphytic red algae Bostrychia radicans and Caloglossa leprieurii (Fig. 1), but not on the green alga Ulva or on live $S$. alterniflora or its young shoots. When offered a choice among salt marsh macrophytes, amphipods fed on dead $S$. alterniflora in preference to all other plants (Fig. 1). When offered animal versus plant tissues, amphipods fed preferentially on dead $S$. alterniflora relative to tissues from the marsh killifish Fundulus heteroclitus, the grass shrimp Palaemonetes pugio, or the mud snail Illyanassa obsoleta (Fig. 2).

\section{Plant traits affecting feeding preferences}

Dead cordgrass and Ulva were the softest macrophytes that could be tested with the penetrometer (Table 1). The red alga Caloglossa leprieurii was softer than the lowest mass our penetrometer could measure. The filamentous red alga Bostrychia radicans could not be tested because of its slender morphology, but it was not overly 'tough' or rough to the touch. Live cordgrass was the toughest tissue tested (Table 1).

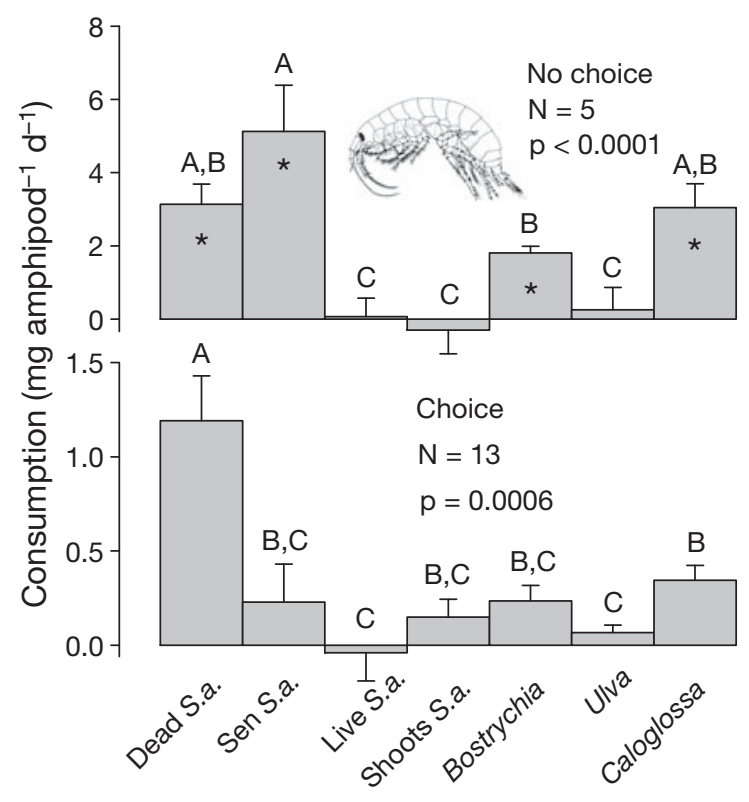

Fig. 1. Gammarus palustris. No-choice and multiple choice assays for amphipods feeding on 7 different macrophyte diets, mean \pm SE (S.a.: Spartina alterniflora; sen: senescent). Statistics are from Kruskal-Wallis and Friedman tests, respectively. Bars with the same letters were not significantly different in post hoc multiple comparison tests across treatments within each of the 2 separate assays. *Significant loss of plant mass in treatments with amphipods (i.e. the amphipods fed on plant material) vs. controls without amphipods (paired $t$-tests)

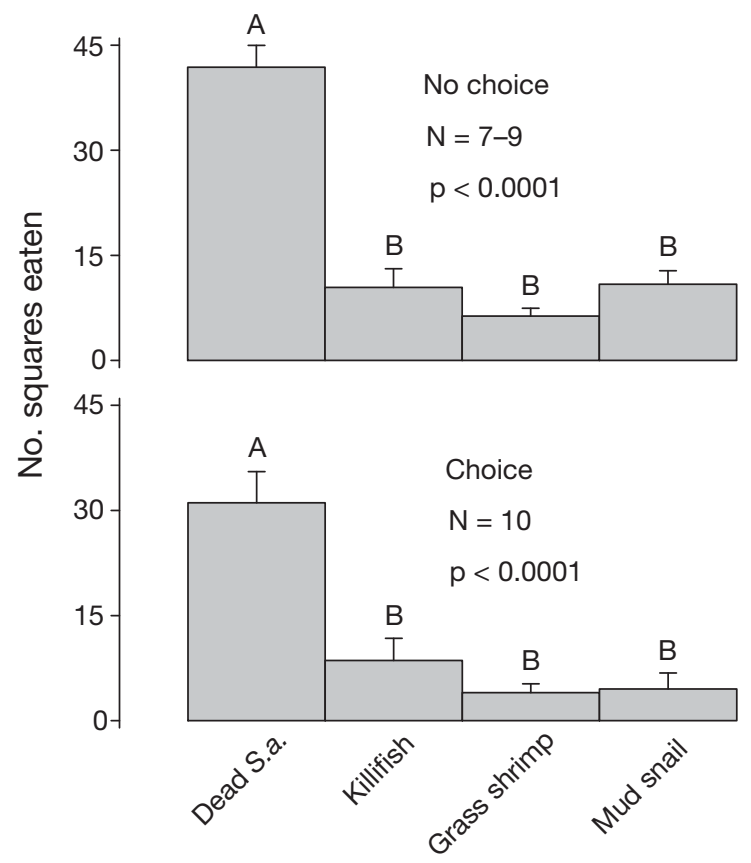

Fig. 2. Gammarus palustris. No-choice and multiple choice assays for amphipods feeding on dead Spartina alterniflora (S.a.) vs. animal tissue, mean \pm SE. Statistics are from Kruskal-Wallis and Friedman tests, respectively. Bars with the same letters were not significantly different in post hoc multiple comparison tests across treatments within each assay 
Table 1. Food quality parameters of potential diets. Data are mean $\pm \mathrm{SE}(\mathrm{N}) ;$ S.a.: Spartina alterniflora and Sen: senescent. Different superscripts denote statistical differences among means via 1-way ANOVAs followed by Tukey tests. Toughness was assessed using a penetrometer to determine the mass required to pierce each plant

\begin{tabular}{|lcccr|}
\hline Diet & Toughness $(\mathrm{g})$ & $\% \mathrm{C}$ & $\% \mathrm{~N}$ & $\mathrm{C}: \mathrm{N}$ \\
\hline Dead S.a. & $4.81 \pm 0.432(5)^{\mathrm{a}}$ & $26.6 \pm 1.86(14)^{\mathrm{c}}$ & $0.428 \pm 0.017(14)^{\mathrm{a}}$ & 62.15 \\
Sen S.a. & $48.3 \pm 6.95(5)^{\mathrm{c}}$ & $31.2 \pm 0.685(15)^{\mathrm{c}, \mathrm{d}}$ & $0.309 \pm 0.023(15)^{\mathrm{a}, \mathrm{d}}$ & 101.0 \\
Live S.a. & $105.0 \pm 6.77(5)^{\mathrm{d}}$ & $33.8 \pm 0.583(10)^{\mathrm{d}}$ & $0.517 \pm 0.030(10)^{\mathrm{a}}$ & 65.38 \\
Shoots S.a. & $34.3 \pm 1.01(5)^{\mathrm{b}}$ & $34.5 \pm 3.22(7)^{\mathrm{d}}$ & $1.37 \pm 0.145(7)^{\mathrm{a}, \mathrm{c}, \mathrm{f}, \mathrm{g}}$ & 25.18 \\
Bostrychia & Could not be tested & $16.7 \pm 1.12(4)^{\mathrm{b}, \mathrm{g}}$ & $2.09 \pm 0.095(5)^{\mathrm{g}}$ & 7.99 \\
Ulva & $5.25 \pm 0.523(5)^{\mathrm{a}}$ & $24.5 \pm 1.87(9)^{\mathrm{c}, \mathrm{e}, \mathrm{f}, \mathrm{g}}$ & $2.83 \pm 0.271(9)^{\mathrm{b}, \mathrm{f}, \mathrm{g}}$ & 8.66 \\
Caloglossa & $<2.68$ & $15.6 \pm 0.092(5)^{\mathrm{b}}$ & $1.76 \pm 0.078(5)^{\mathrm{f}, \mathrm{g}}$ & 8.86 \\
Fish & Not tested & $26.6 \pm 1.04(7)^{\mathrm{c}, \mathrm{d}}$ & $7.52 \pm 0.433(7)^{\mathrm{e}}$ & 3.54 \\
Shrimp & Not tested & $30.4 \pm 0.496(7)^{\mathrm{c}, \mathrm{d}, \mathrm{f}}$ & $8.02 \pm 0.171(7)^{\mathrm{e}}$ & 3.79 \\
Snail & Not tested & $34.1 \pm 1.08(6)^{\mathrm{d}, \mathrm{f}, \mathrm{d}}$ & $8.02 \pm 0.694(6)^{\mathrm{e}}$ & 4.25 \\
Sand & Not tested & $0.064 \pm 0.0005(2)^{\mathrm{a}}$ & $0.011 \pm 0.0006(2)^{\mathrm{a}}$ & 5.82 \\
Mud & Not tested & $2.59 \pm 0.174(2)^{\mathrm{a}}$ & $0.227 \pm 0.002(2)^{\mathrm{a}}$ & 11.41 \\
\hline
\end{tabular}

\section{Amphipod fitness on different diets}

Amphipod survival differed among diets ( $p$ < 0.0001, survival analysis), and was highest on dead Spartina alterniflora relative to all other diets ( $\mathrm{p}<0.0001$, $\chi^{2}$ tests; Fig. 4). Amphipods reared on dead $S$. alterniflora were also 19 to $39 \%$ larger than amphipods reared on other $S$. alterniflora diets $(\mathrm{p}<$ 0.001, Table 2), and there was a trend toward more females reaching sexual maturity on dead $S$. alterniflora

Sand and mud sediments both contained relatively little organic carbon relative to other food sources, whereas animal tissues were the most nitrogen-rich foods tested, containing roughly 4 -fold more nitrogen per dry mass than algal tissues, and 20 -fold more nitrogen than sand, mud, and dead, senescent, and live green Spartina alterniflora (Table 1). Cordgrass tissues had C:N ratios ranging from 25 to 101, which is 47 to $594 \%$ higher than the maximum of 17 thought to sustain animal nutrition (Russell-Hunter 1970).

Amphipods fed readily on all Spartina alterniflora tissues when plant tissues were incorporated into an agar matrix that destroyed their structural traits (Fig. 3). However, feeding was still low on Bostrychia radicans and Ulva.

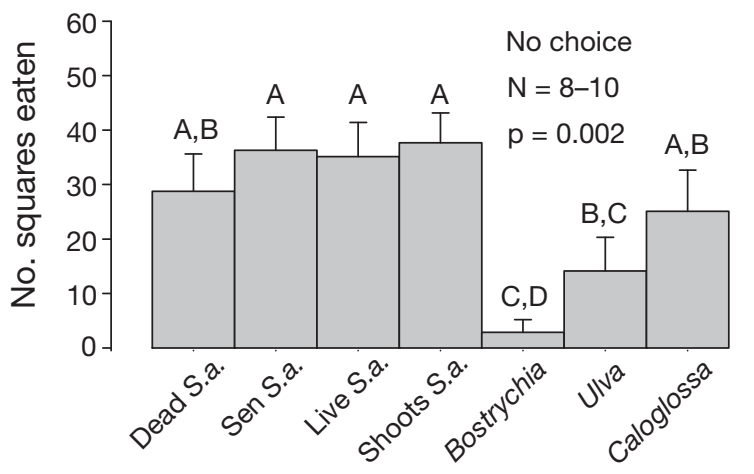

Fig. 3. Gammarus palustris. No-choice feeding assay showing the number of squares eaten by amphipods among 7 artificial plant diets, mean \pm SE. Statistics are from a Kruskal-Wallis test; bars with the same letters were not significantly different in post hoc multiple comparison tests. S.a.: Spartina alterniflora; sen: senescent versus alternative diets ( $p=0.064, \chi^{2}$ test; Table 2 ). Maternal effects could not account for these differences. Although larger mothers had proportionately larger broods ( $\mathrm{p}<0.0001, \mathrm{r}^{2}=0.354$, linear regression), there was no effect of maternal size $\left(p=0.936, r^{2}=0.0\right.$, linear regression) or brood size $\left(p=0.395, r^{2}=0.26\right.$, linear regression) on final offspring size. There were significant familial differences in offspring lifespan when amphipods were reared on live $S$. alterniflora, the shoots of $S$. alterniflora, and on Ulva (Table 3), suggesting heritable variation for amphipod performance on these diets.

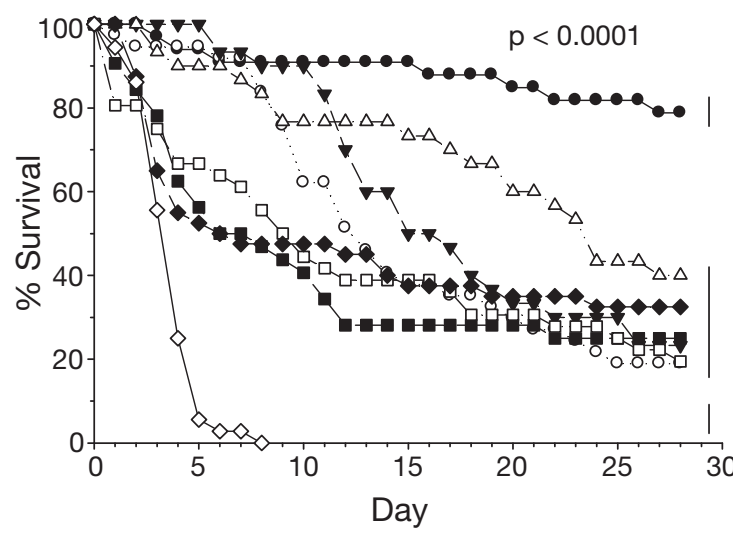

\begin{tabular}{|lll|}
\hline - Dead S.a. (33) & Shoots S.a. (32) & ○ Caloglossa (37) \\
$\Delta$ Sen S.a. (30) & $\square$ Ulva (32) & $\diamond$ Starvation (36) \\
$\bullet$ Live S.a. (40) & $\nabla$ Bostrychia (30) & \\
\hline
\end{tabular}

Fig. 4. Gammarus palustris. Survival of amphipods on 7 different macrophyte diets and a starvation control. Significance and groupings (shown by vertical lines to the right of the plot) are from $\chi^{2}$ analyses of survivorship on Day 28. Numbers in parentheses are the number of individuals reared on each diet. S.a.: Spartina alterniflora; sen: senescent 
Table 2. Gammarus palustris. Mean $\pm \mathrm{SE}(\mathrm{N})$ total length of all amphipods surviving to Day 28, and \% of female amphipods that reached sexually maturity when reared on different macrophyte diets. Different letters denote statistical differences via 1-way ANOVA followed by Tukey's test. S.a.: Spartina alterniflora, Sen: senescent

\begin{tabular}{|lcc|}
\hline Diet & Survivor size $(\mathrm{mm})$ & \% Sexually mature + \\
\hline Dead S.a. & $4.25 \pm 0.197(26)^{\mathrm{a}}$ & $72.2(18)$ \\
Sen S.a. & $3.06 \pm 0.184(10)^{\mathrm{b}}$ & $25.0(8)$ \\
Live S.a. & $3.19 \pm 0.133(14)^{\mathrm{b}}$ & $0(11)$ \\
Shoots S.a. & $3.36 \pm 0.139(8)^{\mathrm{b}}$ & $14.3(7)$ \\
Bostrychia & $3.27 \pm 0.211(7)^{\mathrm{b}}$ & $0(6)$ \\
Ulva & $3.58 \pm 0.208(7)^{\mathrm{a}, \mathrm{b}}$ & $20.0(5)$ \\
Caloglossa & $3.42 \pm 0.178(7)^{\mathrm{a}, \mathrm{b}}$ & $25.0(4)$ \\
\hline
\end{tabular}

Table 3. Gammarus palustris. Separate 1-way ANOVAs testing for familial differences in the lifespan of offspring reared on different diets. Bold values were significant at $\mathrm{p}<0.05$. S.a.: Spartina alterniflora, Sen: senescent

\begin{tabular}{|lcrcc|}
\hline Diet & df & MS & $F$ & p \\
\hline Dead S.a. & 2,29 & 1.4 & 0.02 & 0.975 \\
Sen S.a. & 5,22 & 41.6 & 0.47 & 0.796 \\
Live S.a. & 4,35 & 577.7 & 7.35 & $<\mathbf{0 . 0 0 0 1}$ \\
Shoots S.a. & 4,26 & 282.3 & 3.42 & $\mathbf{0 . 0 2 2}$ \\
Bostrychia & 5,23 & 27.2 & 0.44 & 0.813 \\
Ulva & 5,25 & 262.3 & 3.61 & $\mathbf{0 . 0 1 4}$ \\
Caloglossa & 3,33 & 26.0 & 0.37 & 0.773 \\
\hline
\end{tabular}

\section{Stable isotope determination of marsh producers and consumers}

Idealized trophic fractionation factors assume shifts of $1 \%$ o $\delta^{13} \mathrm{C}$ and $3.5 \% \delta^{15} \mathrm{~N}$ for consumers feeding on a food source (DeNiro \& Epstein 1978, 1981, Minagawa \& Wada 1984, Vanderklift \& Ponsard 2003). Thus, mean isotope values of field-collected samples suggested that the organic contents of mud sediments (i.e. small particulate detrital matter and benthic microalgae on the marsh surface) were likely the primary diet source fueling Gammarus palustris, Uhlorchestia spartinophila, Palaemonetes pugio, and Ilyanassa obsoleta (Fig. 5). The endpoint for this production, particularly for production of G. palustris, appeared to be marsh killifish Fundulus heteroclitus. Using the idealized trophic fractionation factors, one would conclude that consumers were not subsisting on diets of cordgrass, macroalgae, or the organic contents of sand sediments.

However, the isotope values of amphipods reared on known diet sources since birth did not reflect idealized trophic shifts. In particular, $\delta^{13} \mathrm{C}$ values for amphipods reared on cordgrass diets were 0.47 to $5.08 \%$ more ${ }^{13} \mathrm{C}$ depleted than their food source (Fig. 5), in contrast to the expected $1 \%{ }^{13} \mathrm{C}$ enrichment. This occurred in

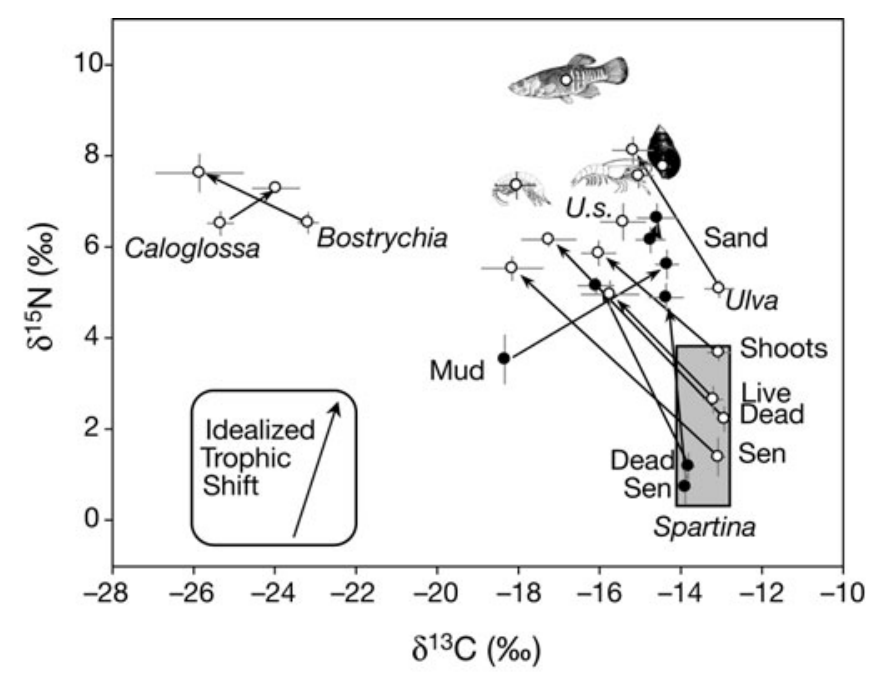

Fig. 5. Dual isotope plot depicting mean $( \pm \mathrm{SE}) \delta^{15} \mathrm{~N}$ and $\delta^{13} \mathrm{C}$ values for sediments, primary producers, and consumers, expressed as parts per mil (\%o). Icons represent the amphipod Gammarus palustris, the killifish Fundulus heteroclitus, the snail Illyanassa obsoleta, and the shrimp Palaemonetes pugio. U.s.: salt-marsh amphipod Uhlorchestia spartinophila. Open and filled symbols: samples collected in 2000 and 2001, respectively. Arrows attached to symbols: observed trophic shifts for G. palustris reared on known food sources since birth. Idealized trophic shift is $1 \% \delta^{13} \mathrm{C}$ and $3.5 \% \delta^{15} \mathrm{~N}$ for a consumer feeding on any given food source. Sen: senescent

both years regardless of whether samples had been preserved in formalin. Amphipods reared on dead cordgrass and fixed in formalin were ${ }^{15} \mathrm{~N}$-enriched $(1.0 \%)$ and ${ }^{13} \mathrm{C}$-depleted $(1.2 \%)$ relative to amphipods that were reared on dead cordgrass but never fixed. These values are consistent with published effects of formalin preservation (Sarakinos et al. 2002). Unexpected $\delta^{13} \mathrm{C}$ and $\delta^{15} \mathrm{~N}$ shifts were also found for amphipods feeding on algal and sand diets (Fig. 5); only the marsh mud diet resembled idealized fractionation factors.

\section{DISCUSSION}

One hypothesis for why the 'world is green' is that live plant tissues are often chemically and structurally defended from herbivores (Rosenthal \& Berenbaum 1992), and only upon leaf death does most plant material get incorporated into food webs (Mann 1988, Cebrian 1999). Salt marshes are one of the world's 'greenest' ecosystems, with annual productivity rivaling that of coral reefs and tropical rain forests (Silliman \& Bortolus 2003). Our study suggests that salt marshes are 'green' because the living plants are physically and chemically resistant to the invertebrate consumers that dominate contemporary marshes. 
The common salt marsh amphipod Gammarus palustris strongly preferred dead over live cordgrass Spartina alterniflora in laboratory feeding assays (Fig. 1), and live cordgrass was 7 - to 20 -fold tougher than dead tissues (Table 1). However, when the toughness of live plant tissues was destroyed by grinding and incorporation into a soft agar matrix, amphipods consumed equal amounts of live, senescent, and dead cordgrass, (Fig. 3). Similarly, the omnivorous marsh crab Armases cinereum also consumes live cordgrass following destruction of its physical toughness (Pennings et al. 1998); thus, salt marsh plants appear to be too tough for consumption by common marsh invertebrates. Chemical defenses may also be important, as phenolic acids and other water-soluble extracts from senescent and live $S$. alterniflora deter feeding by invertebrate and vertebrate consumers (Buchsbaum et al. 1984, Valiela \& Rietsma 1984, Bärlocher \& Newell 1994, Pennings et al. 1998). The solubility of these types of defenses may have allowed them to leach from our artificial foods, thus underestimating their possible effects.

Detrital feeding often requires assistance from microbial processing. Fungi and bacteria soften plant tissues, neutralize consumer-deterrent phenolic acids in Spartina alterniflora (Newell 1993), and can increase the nutritional value of such plant material (Findlay \& Tenore 1982, Bärlocher \& Newell 1994). In marked contrast to intense animal-microbe competition for more energy-rich resources (Burkepile et al. 2006), this 'microbial conditioning' of leaf litter appears to be a general phenomenon enhancing the palatability of leaf litter to detritivores (Bärlocher 1980). As a possible example, this conditioning may explain why amphipods ignored senescent cordgrass in the presence of dead cordgrass (Fig. 1), performed poorly on senescent relative to dead cordgrass (Fig. 4, Table 2), yet were willing to feed on senescent cordgrass in the absence of alternative diets (Fig. 1).

The plant traits that precluded feeding on other macrophytes were less clear but suggestive of chemical defenses. The green alga Ulva was physically soft and nutritious relative to cordgrass (Table 3), but was not eaten as fresh tissues and was consumed in only limited amounts when incorporated into agar (Figs. 1 \& 3, see also Borowsky \& Borowsky 1987), suggesting a chemical defense. Gammarus palustris is inhibited by chemical extracts from Ulva (Borowsky \& Borowsky 1990), and Ulva spp. produce dimethylsulfoniopropionate (DMSP), a precursor compound that is activated into more toxic compounds (acrylic acid and dimethyl sulfide) when algal cells are ruptured by herbivores (Van Alstyne \& Puglisi 2007). In contrast, the filamentous red alga Bostrychia radicans was eaten at modest levels when presented as fresh tissues but was rejected when incorporated into agar (Figs. 1 \& 3). Reasons for this difference in palatability are unclear, but it is possible that this alga has compounds that interact with the agar matrix to reduce its utility as a food, or that it has defenses that are activated by the process of grinding and incorporation into agar (Cetrulo \& Hay 2000).

Differential predation risk may also explain restricted host-use by Gammarus palustris. G. palustris resides almost exclusively within the leaf interstices of Spartina alterniflora and only sparingly on other marsh substrates (Gable \& Croker 1977, van Dolah 1978, this study). This pattern is not explained by competition for space; instead, intense predation by marsh killifish Fundulus heteroclitus limits G. palustris to the protection of cordgrass stems (Van Dolah 1978). Moreover, stable isotope values suggest that killifish derive a large portion of their diet from G. palustris (Fig. 5). Thus, predation risk likely restricts G. palustris to cordgrass stems, whereas food cues like plant toughness and secondary chemistry restrict feeding to decaying cordgrass versus other commonly available macrophytes.

The evolution of host-plant specialization has been widely studied among herbivorous insects and some marine amphipods (Bernays \& Graham 1988, Poore et al. 2008), but less so among detritivores. Gammarus palustris is an apparent specialist on dead Spartina alterniflora but possesses the evolutionary 'raw material' necessary for a diet breadth expansion, particularly onto the green alga Ulva. Gammarus palustris exhibited heritable variation for survival on the shoots and live tissues of S. alterniflora and on Ulva (Table 3), with some families surviving the duration of the experiment on these tissues and others rapidly perishing. Diet choice is under genetic control in G. palustris, with particular genotypes possessing distinct salivary enzymes leading to preferential consumption of Ulva over other macrophytes (Borowsky et al. 1985, Guarna \& Borowsky 1993). Amphipods in our study did not tend to consume Ulva (Fig. 1), but the presence of heritable variation for feeding and survival on alternate hosts suggests that $G$. palustris could use hosts other than $S$. alterniflora. This genetic potential may be stunted by ecological factors like predation risk in the field (e.g. Duffy \& Hay 1994, Poore \& Steinberg 2001), or by the temporal and spatial variability of hosts like Ulva compared to more predictable hosts like $S$. alterniflora.

Stable isotopes are widely used for rapid and integrated pictures of consumer diet, trophic position, and the general flow of energy and materials through food webs. The basic assumptions are that primary producers possess distinct isotope ratios, and most importantly, that producer isotopes are passed on to consumers in predictable shifts of $\Delta \delta^{13} \mathrm{C}=1 \%$ and $\Delta \delta^{15} \mathrm{~N}=$ $3.5 \%$ for each trophic transfer (DeNiro \& Epstein 1978, 
1981, Minagawa \& Wada 1984, Vanderklift \& Ponsard 2003). Our initial analysis of stable isotope ratios suggested that field populations of Gammarus palustris incorporated most of their carbon from detrital and microalgal food sources associated with marsh mud, not from dead Spartina alterniflora (Fig. 5). However, a direct test of this hypothesis showed that the isotope values of laboratory amphipods reared on marsh mud were enriched in ${ }^{13} \mathrm{C}$ and thus dissimilar from field-collected G. palustris (Fig. 5), suggesting marsh mud contents as an unlikely diet source for G. palustris.

The isotope values of amphipods reared in the laboratory on dead Spartina alterniflora, however, closely resembled field-collected amphipods (Fig. 5), and Gammarus palustris clearly inhabits, preferentially feeds on, and performs best on diets of dead S. alterniflora over all other hosts tested (Figs. 1-3, Table 2). All findings suggest that field amphipods derive a large portion of their diet from dead cordgrass. We could not have reached this conclusion without using controlled assimilation assays. Amphipods reared on dead S. alterniflora were depleted by over $3 \%$ in ${ }^{13} \mathrm{C}$ relative to their food source, not enriched by the expected $1 \%$ ${ }^{13} \mathrm{C}$. Moreover, formalin effects could not explain the general isotopic resemblance of laboratory amphipods reared on cordgrass to field-collected amphipods (Fig. 5); both fixed and unfixed amphipods reared on live, senescent, or dead cordgrass exhibited similar directions in trophic shift, i.e. ${ }^{13} \mathrm{C}$-depleted rather than enriched.

Fractionation by crustaceans in particular is highly variable, often showing unpredictable levels of ${ }^{15} \mathrm{~N}$ enrichment and ${ }^{13} \mathrm{C}$-depletion rather than enrichment (Vanderklift \& Ponsard 2003, Crawley et al. 2007). Potential explanations include differential assimilation of ${ }^{13} \mathrm{C}$-depleted compounds like plant lipids or bacteriallydegraded lignin (Benner et al. 1987, van Dongen et al. 2002), fasting (Vander Zanden \& Rasmussen 2001), and the consumption of N-poor foods (Vanderklift \& Ponsard 2003). In our study, a likely explanation is that amphipods in the field augment diets of dead cordgrass with epiphytic algae, consistent with gut content observations of algal remains (Gable \& Croker 1977), and with our observations that amphipods consumed the 2 ephiphytic red algae Bostrychia radicans and Caloglossa leprieurii in the laboratory (Fig. 1). Although the isotope composition of amphipods reared on epiphytic algae did not resemble values for field amphipods (Fig. 5), both diets were ${ }^{15} \mathrm{~N}$-enriched and ${ }^{13} \mathrm{C}$-depleted relative to dead cordgrass. Thus, opportunistic algal consumption could result in ${ }^{15} \mathrm{~N}$-enrichment and ${ }^{13} \mathrm{C}$-depletion relative to a diet of dead cordgrass alone (Fig. 5), further demonstrating the value of combining dietary and stable isotope data to infer food web structure (see also Winemiller et al. 2007).
The isotope content of marsh killifishes Fundulus heteroclitus suggests predation on Gammarus palustris (Fig. 5), a tentative conclusion given that we did not verify this trophic fractionation with assimilation assays. Nevertheless, it is consistent with field and laboratory experiments showing that killifish are often the major source of mortality for G. palustris and other marsh invertebrates (Vince et al. 1976, van Dolah 1978, Kneib 1982), and with other isotope analyses suggesting killifish are major predators in marsh food webs (Currin et al. 1995, Wainright et al. 2000). Thus, consumption of $G$. palustris and similar marsh invertebrates by $F$. heteroclitus may be an important trophic pathway linking cordgrass production to nearshore food webs (Covi \& Kneib 1995, Kneib et al. 1997), a pathway made possible because microbes liberate cordgrass production that in life is protected by structural and chemical defenses.

Acknowledgements. We thank E. Kinard, J. Long, D. Burkepile, A. Hollebone, C. Kicklighter, D. Hasan, R. Kneib, and S. Pennings for assistance with amphipod collections, rearing, and identification, C. Payne for stable isotope analyses, and 3 anonymous reviewers for constructive comments on the manuscript. Support was provided by an NSF IGERT grant DGE 0114400 and the Teasley Endowment to Georgia Tech.

\section{LITERATURE CITED}

Bärlocher F (1980) Leaf-eating invertebrates as competitors of aquatic hyphomycetes. Oecologia 47:303-306

Bärlocher F, Newell SY (1994) Phenolics and proteins affecting palatability of Spartina leaves to the gastropod Littoraria irrorata. PSZN I: Mar Ecol 15:65-75

Benner R, Fogel ML, Sprague EK, Hodson RE (1987) Depletion of ${ }^{13} \delta \mathrm{C}$ in lignin and its implications for stable carbon isotope studies. Nature 329:708?710

> Bernays E, Graham M (1988) On the evolution of host specificity in phytophagous arthropods. Ecology 69:886-892

Borowsky B, Borowsky R (1987) Feeding by the salt-marsh amphipod, Gammarus palustris on Ulva and Enteromorpha. Am Zool 27:55A (abstract)

> Borowsky R, Borowsky B (1990) Feeding inhibition of the saltmarsh amphipod Gammarus palustris Bousfield, 1969, by heat-labile substances in Ulva lactuca L. Crustaceana 59: 299-301

> Borowsky R, Borowsky B, Milani H, Greenberg P (1985) Amylase variation in the salt-marsh amphipod, Gammarus palustris. Genetics 111:311-323

> Buchsbaum R, Valiela I, Swain T (1984) The role of phenolic compounds and other plant constituents in feeding by Canada geese in a coastal marsh. Oecologia 63:343-349

Burkepile DE, Parker JD, Woodson CB, Mills HJ, Kubanek J, Sobecky PA, Hay ME (2006) Chemically mediated competition between microbes and animals: microbes as consumers in food webs. Ecology 87:2821-2831

Cebrian J (1999) Patterns in the fate of production in plant communities. Am Nat 154:449-468

$>$ Cetrulo GL, Hay ME (2000) Activated chemical defenses in tropical versus temperate seaweeds. Mar Ecol Prog Ser 207:243-253

Covi M, Kneib R (1995) Intertidal distribution, population 
dynamics and production of the amphipod Uhlorchestia spartinophila in a Georgia, USA, salt marsh. Mar Biol 121: $447-455$

> Crawley KR, Hyndes GA, Vanderklift MA (2007) Variation among diets in discrimination of ${ }^{13} \delta \mathrm{C}$ and ${ }^{15} \mathrm{\delta N}$ in the amphipod Allorchestes compressa. J Exp Mar Biol Ecol 349:370-377

Currin C, Newell S, Paerl HW (1995) The role of standing dead Spartina alterniflora and benthic microalgae in saltmarsh food webs - considerations based on multiple stable-isotope analysis. Mar Ecol Prog Ser 121:99-116

DeNiro MJ, Epstein S (1978) Influence of diet on the distribution of carbon isotopes in animals. Geochim Cosmochim Acta 42:495-506

DeNiro MJ, Epstein S (1981) Influence of diet on the distribution of nitrogen isotopes in animals. Geochim Cosmochim Acta 45:341-351

Duffy J, Hay M (1994) Herbivore resistance to seaweed chemical defense - the roles of mobility and predation risk. Ecology 75:1304-1319

Findlay S, Tenore K (1982) Nitrogen source for a detritivore: detritus substrate versus associated microbes. Science 218:371-373

Gable M, Croker R (1977) The salt marsh amphipod, Gammarus palustris Bousfield, 1969 at the northern limit of its distribution. I. Ecology and life cycle. Estuar Coast Mar Sci 5:123-134

Guarna MM, Borowsky RL (1993) Genetically controlled food preference: biochemical mechanisms. Proc Natl Acad Sci USA 90:5257-5261

Hay M, Stachowicz J, Cruz-Rivera E, Bullard S, Deal M, Lindquist N (1998) Bioassays with marine and freshwater macroorganisms. In: Haynes K, Millar J (eds) Methods in chemical ecology, Vol 2. Chapman \& Hall, New York, p 39-141

Kneib R (1982) Habitat preference, predation, and the intertidal distribution of gammaridean amphipods in a North Carolina salt marsh. J Exp Mar Biol Ecol 59:219-230

Kneib RT, Newell SY, Hermeno ET (1997) Survival, growth and reproduction of the salt-marsh amphipod Uhlorchestia spartinophila reared on natural diets of senescent and dead Spartina alterniflora leaves. Mar Biol 128:423-431

Mann KH (1988) Production and use of detritus in various freshwater, estuarine, and coastal marine ecosystems. Limnol Oceanogr 33:910-930

> Mattson W (1980) Herbivory in relation to plant nitrogen content. Annu Rev Ecol Syst 11:119-161

> Minagawa M, Wada E (1984) Stepwise enrichment of ${ }^{15} \mathrm{~N}$ along food chains: further evidence and the relation between $\delta^{15} \mathrm{~N}$ and animal age. Geochim Cosmochim Acta 48:1135-1140

Newell SY (1993) Decomposition of shoots of a salt-marsh grass. Adv Microb Ecol 13:301-326

Odum WE, Kirk PW, Zieman JC (1979) Non-protein nitrogen compounds associated with particles of vascular plant detritus. Oikos 32:363-367

Pennings SC, Carefoot TH, Siska EL, Chase ME, Page TA (1998) Feeding preferences of a generalist salt-marsh crab: relative importance of multiple plant traits. Ecology 79:1968-1979

Polis GA, Strong DR (1996) Food web complexity and commu-

Editorial responsibility: Robert Feller,

Columbia, South Carolina, USA nity dynamics. Am Nat 147:813-846

Poore AGB, Steinberg PD (2001) Host-plant adaptation in an herbivorous marine amphipod: genetic potential not realized in field populations. Evolution 55:68-80

Poore AGB, Hill NA, Sotka EE (2008) Phylogenetic and geographic variation in host breadth and composition by herbivorous amphipods in the family Ampithoidae. Evolution 62:21-38

Rietsma CS, Valiela I, Buchsbaum R (1988) Detrital chemistry, growth, and food choice in the salt-marsh snail (Melampus bidentatus). Ecology 69:261-266

Rosenthal GA, Berenbaum MR (eds) (1992) Herbivores: their interactions with secondary metabolites: evolutionary and ecological processes. Academic Press, San Diego, CA

Russell-Hunter WD (1970) Aquatic productivity: an introduction to some basic aspects of biological oceanography and limnology.Collier MacMillan, London

Sarakinos HC, Johnson ML, Vander Zanden MJ (2002) A synthesis of tissue-preservation effects on carbon and nitrogen stable isotope signatures. Can J Zool 80:381-387

Silliman BR, Bortolus A (2003) Underestimation of Spartina productivity in western Atlantic marshes: marsh invertebrates eat more than just detritus. Oikos 101:549-554

Silliman BR, Newell SY (2003) Fungal farming in a snail. Proc Natl Acad Sci USA 100:15643-15648

Teal JM (1962) Energy flow in the salt marsh ecosystem of Georgia. Ecology 43:614-624

Valiela I, Rietsma CS (1984) Nitrogen, phenolic acids, and other feeding cues for salt marsh detritivores. Oecologia 63:350-356

Van Alstyne KL, Puglisi MP (2007) DMSP in marine macroalgae and macroinvertebrates: distribution, function, and ecological impacts. Aquat Sci 69:394-402

> Van Dolah R (1978) Factors regulating the distribution and population dynamics of the amphipod Gammarus palustris in an intertidal salt marsh community. Ecol Monogr 48:191-217

> Van Dongen BE, Schouten S, Sinninghe Damsté JS (2002) Carbon isotope variability in monosaccharides and lipids of aquatic algae and terrestrial plants. Mar Ecol Prog Ser 232:83-92

Vander Zanden MJ, Rasmussen JB (2001) Variation in $\delta^{15} \mathrm{~N}$ and $\delta^{13} \mathrm{C}$ trophic fractionation: implications for aquatic food web studies. Limnol Oceanogr 46:2061-2066

- Vanderklift MA, Ponsard S (2003) Sources of variation in consumer-diet ${ }^{15} \mathrm{~N}$ enrichment: a meta-analysis. Oecologia 136:169-182

- Vince S, Valiela I, Backus N, Teal J (1976) Predation by the salt marsh killifish Fundulus heteroclitus (L.) in relation to prey size and habitat structure: consequences for prey distribution and abundance. J Exp Mar Biol Ecol 23:255-266

> Wainright SC, Weinstein MP, Able KW, Currin CA (2000) Relative importance of benthic microalgae, phytoplankton and the detritus of smooth cordgrass Spartina alterniflora and the common reed Phragmites australis to brackishmarsh food webs. Mar Ecol Prog Ser 200:77-91

Winemiller KO, Akin S, Zeug SC (2007) Production sources and food web structure of a temperate tidal estuary: integration of dietary and stable isotope data. Mar Ecol Prog Ser 343:63-76

Submitted: February 4, 2008; Accepted: March 31, 2008 Proofs received from author(s): July 7, 2008 